\title{
Cholo Politics and Urban Indigenous Self-Fashioning in Bolivia
}

Robert Albro

American University

\begin{abstract}
This article reviews recent ethnographic approaches to indigeneity in Bolivia from the global north. It examines some consequences of ethnographic choices to treat indigeneity as primarily a political challenge of power and inclusion, where indigenous identity is understood to be most characteristically expressed in collective terms or through social mobilization. At the same time, it also assesses a complementary ethnographic focus upon legacies of neoliberalism, as a major context for situating contemporary indigenous projects in Bolivia, specifically, ethnographic contrasts drawn between political indigeneity and the liberal subject. Finally, this article offers an account of indigenous sensemaking for the urban landscape of Quillacollo and explores the relevance of indigenous claims as integral to that small city's "cholo politics," and as an alternative means of understanding the construction of indigenous subjects.
\end{abstract}

\section{Keywords}

Cholo politics, collective versus individual, cultural critique, neoliberalism, self-fashioning, the liberal subject, urban indigeneity 


\section{Resumen}

Este artículo examina aproximaciones etnográficas a la cuestión de la indigeneidad en Bolivia desde la perspectiva del norte global. Se examinan algunas consecuencias del enfoque etnográfico en el estudio de la indigeneidad como desafío político y de inclusión, donde la identidad indígena se expresa fundamentalmente en términos colectivos y a través de movilizaciones sociales. El artículo también evalúa los alcances de un enfoque etnográfico sobre el impacto del neoliberalismo en Bolivia, entenido como un contexto importante para situar los proyectos indígenas contemporáneos, específicamente los contrastes entre la indigeneidad política y el sujeto liberal. Finalmente, el artículo ofrece una descripción de la comprensión indígena del paisaje urbano de Quillacollo y explora la relevancia de las demandas indígenas como parte integral de la "política chola" de esta pequeña ciudad y como una forma alternativa de comprender la construcción de sujetos indígenas.

\section{Palabras claves}

Autoconstrucción de sujeto, colectivo versus individual, crítica cultural, indigeneidad urbana, neoliberalismo, políticas cholas, sujeto liberal

\section{Introduction}

"Cholo" is an insulting term heard with a great deal of regularity in Quillacollo, recently grown into a small satellite city and composing part of the urban periphery of the nearby much larger city of Cochabamba. A pejorative throughout the Andes, cholos, or "citified Indians," are described in morally ambiguous terms as rural people of indigenous descent recently moved to the city in pursuit of upward mobility. Understood to be betwixt and between, and in a state of social and cultural transition, cholos reject and sometimes attempt to conceal their origins and ancestry, if usually unsuccessfully. In Quillacollo's fast-changing urban landscape, discourses of cholaje are about stigma, loss and alienation. But, particularly in light of the turn-of-the century emergence of neo-popular and indigenous political alternatives - with the ascendancy of Evo Morales and the Movement Toward Socialism (MAS), Quillacollo would quickly be dominated by the MAS -the label, cholo, has surprisingly also acquired an ambiguously positive valence, as a means of partial if contested access to "humble" Andean indigenous ancestry and fluency, as a personally-relevant cultural heritage. The evolving sociocultural dynamics of cholaje in places like Quillacollo, and their relation to the constitution of new kinds of indigenous 
subjects, offer an opportunity to reflect on ethnographic treatments of indigeneity in Bolivia.

In Quillacollo at least what people refer to as humble personhood (someone "de origin humilde") is routinely publicly negotiated and constituted through the interplay of insult and embrace, intimacy and absence, or place and displacement. I have elsewhere used the term "estrangement" to identify the sociocultural dialectics of recognition and misrecognition that inform often publicly contested claims to self, and movements in and out of indigenous and nonindigenous terms of local experience, enabled by the displacement and reinvention of cultural heritage (Albro 2010a, 121-151). Public arguments about heritage are carried out using the lexicon of fiesta sponsorship, kinship, genealogy and contested relationships to ancestral sources in ways comparable to discussions of collective memory and social reproduction in other parts of the Bolivian Andes (see Abercrombie 1998). If public, and fractiously social, however, these claims of indigeneity in Quillacollo are composed over the course of long careers and are not necessarily part of a collective indigenous politics or identity. Nor do typically urban-located indigenously-identified collective protests or calls for self-determination or autonomy in the terms of collective rights exhaust indigeneity's meanings in arenas like Quillacollo's, where identity claims are made, and come to publicly matter, in spaces of contention between their rejection and intimate embrace. This is a different way of thinking about indigenous locations than we typically encounter in ethnographic terms.

Ethnographers and ethnohistorians have over time made a point of exploding the perception, often from afar, that in Bolivia indigeneity is best understood as a comprehensive or unitary category, or that it refers narrowly to a given group or mode of being. Researchers have, instead, chronicled the diversity of forms of indigeneity in this Andean country, an issue which continues to demand attention in the early twenty-first century, as indigenous politics have moved steadily toward the center of Bolivia's political conversation. This is, of course, largely a consequence of the MAS government undertaking an historic political project of decolonization and empowerment of this country's majority indigenous population, since it came to power in 2006. Not surprisingly, much published ethnography over the previous decade has also taken up the question of how to register, and understand, the changing and increasingly plural terms of indigenous participation in Bolivian public life, emphasizing new forms of activism and social movement organizing just prior to and during the MAS era. 
While I suspect that most ethnographers of Bolivia would readily agree with Andrew Canessa $(2007,197)$ that the meaning of "indigenous" is "highly variable, context specific and changes over time," exploring the range of variation of how this is specifically the case remains an important task. As Canessa $(2007,2012,2014)$ has examined in his own research and writing, even as indigenous activisms often take the form of historical projects of political, social and cosmological continuity, recovery and memory (e.g. Mamani Condori 1991, Ari 2014), from precolonial through colonial to contemporary eras, in Bolivia the embrace of indigeneity as a basis for projects of political power and representation also composes a relatively recent set of developments. Indigenous claim making can have various instrumental purposes, take multiple expressive forms, and contribute in different ways to social processes constituting cultural and political subjects, including subjects not primarily or exclusively indigenous. But if indigenous people, groups, and movements represent a diverse array of commitments, which have in recent years occasionally conflicted with MAS government priorities, ethnographers of Bolivia have so far largely chosen to interpret such diversity as a political question.

As a subject of contested signifying practices, however, "indigeneity" can be about an open-ended variety of claims, starting with self-identity. As we have seen in Bolivia, it can also be established through constitutional fiat, as a legal entity. The term might continue to carry the historical weight of stigma, as it still does in Bolivia, used to identify specific localities, or to draw contrastive differences, as with highland "originario" and lowland "indígena." Indigeneity can be constituted on the basis of remembered genealogical or ancestral relationships, or heritage claims, or utilized as a tool to access rights and resources as part of forward-looking projects of empowerment and autonomy, or all of the above. What Goodale $(2006,635)$ calls the "Bolivian indigenous imaginary" can participate in envisioning new categories of inclusion, alternative moral universes, and "forms of global belonging." In recent years, indigeneity has even been mobilized as a normative source for Bolivia's interventions in international climate deliberations (see Albro 2018). Nor are these modes of indigenous sense-making necessarily competitive or mutually exclusive. A majority of recent ethnographic attention to indigeneity in Bolivia, however, has focused on interrelated questions of power, movements of political inclusion, and evolving indigenous-state relations. Relatively less attention has been given to other expressive purposes and signifying practices involving indigeneity, such as the negotiation of ancestry or 
patrimony in contexts of rapidly growing but typically mobile or transient urban scenes like Quillacollo's.

The cocaleros of the Chapare, a core MAS constituency, provide a ready example of the emergence of new indigenous alternatives. Through the years of their militant struggle to combat eradication campaigns during the US-led War on Drugs in Bolivia, they were most frequently described, and described themselves, in class terms as "small-scale agriculturalists." However, by the late 1990s and early 2000s, cocalero self-presentation more aggressively incorporated the cultural trappings of indigeneity, engineering a rapprochement of class with ethnicity (Grisaffi 2010). They adroitly combined active promotion of Andean cultural traits with the recognizable lexicon of international indigenous advocacy, which included self-determination, autonomy, recognition of their cultural distinctiveness, territorial rights, access to natural resources, and greater control over their own economic development. To draw a sharp distinction between "peasantries" and "indigenous communities" in the Chapare ignores how the cocaleros have strategically embraced both agendas, or combined them, as situations warrant. As I have argued elsewhere (Albro 2005a), the cultural politics of the cocaleros were integral to the emergence of the MAS as a dominant political force in Bolivia during the mid-2000s. Rather than a separatist ethno-nationalism, their combining of ethnicity with class and promotion of indigenous heritage served an extensive and inclusive purpose, as a blueprint for the construction of a plural largely urban-based coalition that helped to bring the MAS to power.

Silvia Rivera Cusicanqui (1990) has influentially written about the differences between what she calls "liberal democracy" and "ayllu democracy" in Bolivia, from the perspective of "Norte de Potosí." For Rivera, pre-colonial ayllu principles of community-based direct democracy, including the requirement of service, a system of rotating leadership, extensive consultation, and the goals of community consensus and equitable distribution of resources, are irreconcilable with liberal democracy's treatment of the individual citizen, at once rational and proprietary, and as the subject of national economic advancement. For Rivera, therefore, the structure of agrarian unions (sindicatos) in Bolivia is a colonial imposition reproducing colonial forms of domination and political subjecthood. Rivera is clear that indigeneity is compromised if it seeks to poach, or inhabit, historically non-indigenous political structures like unions. She is also skeptical that intercultural exchanges between "indigenous" and "mestizo-creole" subjects in Bolivia could be anything other than internal colonialism. But this would seem to disregard that 
both the 1980s kataristas -a political project with roots in the 1970s Indianist political party of Fausto Reinaga- and the 1990s cocaleros effectively used Bolivia's national union hierarchy to advance their recognizably indigenous agendas.

Even as it makes strong claims about the terms through which projects of indigeneity are recognizable as such, Rivera's analysis helped to establish a recurrent fault line, which we can also identify in the contemporary ethnography of the Bolivian Andes, which often draws zero sum contrasts between indigenous and liberal or neoliberal political alternatives. This has led to a well-developed corpus of critique of so-called neoliberal multiculturalism in Bolivia. Between 1985 and 2006, at least the neoliberal part, in the form of structural adjustment and policies of fiscal austerity, created a great deal of hardship for ordinary Bolivians. Indigenous movements were often in the forefront of the struggle against neoliberal policies during those years. And as Brooke Larson $(2019,295)$ has observed, in her review of recent academic research in Bolivia from the global north, a more "activist scholarship" has embraced "indigenous-centered research agendas and methodologies." Ethnographers collaborate with their indigenous counterparts in projects that seek to decolonize scholarship, and to decenter epistemic starting points like the liberal subject, while also describing and supporting an oppositional politics with the intention of advancing indigenous agency and autonomy. Such a scholarly focus on what we will call, again borrowing from Canessa (2012), "political indigeneity," however, can divert our appreciation for the multiplicity of ways that indigeneity participates, often partially or controversially, in the construction of social and cultural subjects that do not necessarily take the form of collective political projects or movements.

\section{The Indigenous in the Urban?}

Until the last two decades, the majority of ethnographic research in Bolivia was decidedly rural in location, with slight attention given to the growing plurality of urban indigenous life worlds. The four-volume account by Albó, Greaves and Sandoval (e.g. 1981) of in-migration to, and rapid growth and transformation of, Chukiyawu -the Aymara-dominated city of El Alto-was a trailblazing exception. Though, this study was also at pains to highlight the numerous connections in-migrants to El Alto maintained with their rural communities of origin. In recent years, matters have changed: cities have become important settings for much of the very best ethnography of 
indigeneity, a shift in part spurred by scholarly attention to the large-scale urban popular and indigenous mobilizations in Bolivia throughout the early 2000s. We now have a rich and growing diversity of ethnographies of indigenous organization and mobilization in El Alto (Lazar 2008). But we also have ethnographic accounts of indigenous Guaraní politics in what are now the suburbs of Santa Cruz (Postero 2007), and of community organizing around highland indigenous heritage on the periphery of the city of Cochabamba (Goldstein 2004), as well as of the ways indigeneity is variously negotiated, embraced and marginalized in such small cities as Quillacollo (Albro 2010a) and Sacaba (Shakow 2014). To these we can add a growing number of ethnographically grounded accounts of indigeneity, as distributed through Bolivia's increasingly variegated public sphere (e.g. Himpele 2008; Zamorano Villarreal 2017), including overlapping economic and media circuits, and their multiple connections to largely urban popular cultural expressions, festivals and politics.

There is, in short, no dearth of attention these days among ethnographers of Bolivia to intersections of the urban and indigenous. This insightful and growing body of work, however, incorporates some of the same fault lines, or tensions, and in so doing highlights still unresolved questions about the relation of indigenous projects, and heritage, to urban worlds. Perhaps the most familiar of these, expressed in various ways in multiple ethnographic accounts, is the need to distinguish "individual" from "collective," as at cross purposes and as problematically hard to reconcile epistemological, moral, or cultural subject positions. Most commonly, this distinction takes the form of an ethnographic contrast between the fractiously non-indigenous "individual," as a subject of critique, and diverse "collective" indigenous social and political projects, as a basis for advocacy.

Again, Xavier Albó's (1977) account of the "paradox" of simultaneous communitarian and factional features of Aymara social and cultural life in large part set the terms for subsequent approaches to this issue. As Albó tells us, Aymara communities include multiple corporate or collective characteristics. They share the same territory, cooperate in many economic and other tasks, engage in diverse forms of social reciprocity, make decisions in communal assemblies, and participate collectively in annual ritual and ceremonial events. At the same time, he describes Aymara as "individualists," often engaging in divisive ego-driven competition for resources, and expressing distrust, envy, and conflict. Albó emphasizes, as do other studies of indigenous social and cosmological forms in the Andes, the ways in which this schismatic tendency is 
expressed and, to some extent, resolved through the complementarity of multiple structural oppositions. He also subordinates these schismatic tendencies to collective imperatives, describing this tension as a case of "individualism within the group."

Albó had much more to say about this apparent paradox, and how Aymara resolve it. But largely uncommented upon and operating in the background of his account is that irruptions of contentious factionalism are understood to be "historical" expressions of such developments as the emergence of capitalist competition and evangelicalism, or other factors like globalization, mass media messaging, or migration to the city. Collective solidarities, in contrast, are typically described as originating in, or recoveries of, the "traditionally" Andean. One implication, which runs through ethnographic treatments of Bolivia's indigenous peoples but also much Bolivian government policy making and indigenous activism, is that distinct cultural or cosmological and historical logics prevail for how we should understand this antinomy's relevance to indigenous identity and politics. One reason for this, quite simply, is that indigenous assertions of autonomy, self-determination, rights, identity and claims to territory in Bolivia and elsewhere have been self-consciously advanced as collective claims. These assertions take for granted that indigenous cultural, political and legal projects are fundamentally about reclaiming and reproducing a collective indigenous past, present and future. As important as this is, the unquestioned elision of "indigenous" with "collective" has at times redirected attention from how indigenous lives are lived in Bolivia, more specifically how indigeneity is made meaningful in diverse urban life worlds, and accompanying strategies of sense-making, in ways not straightforwardly aligning with a self-evidently corporate politics.

Ethnographic accounts of indigeneity in Bolivia regularly navigate the individual-collective divide. Postero's (2007) well-researched and illuminating discussion of a suburban Guarani community in Santa Cruz, and its responses to national neoliberal and multicultural reforms, emphasizes how Guaranis view communal control of territory to be a necessary precondition for the effective promotion of indigenous rights and cultural survival. The fact of individual land tenure, considered an important basis for national citizenship and first extended to indigenous peoples by the state as a consequence of Bolivia's 1953 Agrarian Reform, has also led to conflicts among Guaranis over how to prioritize the possibilities enabled by competing individual and communal land claims. Postero's analysis is more nuanced than this brief detour allows. But, as she demonstrates, the legal, political and economic 
contours of individual liberal subjecthood, and consolidation of more transactional and clientelistic indigenous-state relations, contend with and disrupt traditional and collective notions of Guarani identity and modes of selfrepresentation.

Postero explores the tradeoff that in order to become fully entitled citizens Guaranis need to give up traditional forms of communal governance and land-holding, in other words, to stop being Indian. Traveling similar ground, Fabricant's (2012) excellent ethnography identifies and unpacks contradictions in Bolivia's Landless Movement (MST). These include the discord introduced by members' desire to maintain collective land tenure and individual landholdings. Fabricant's vivid ethnography chronicles how MST activists have occupied unproductive land to build collective farms, an effort informed by their parallel re-imagining of the concept of the indigenous ayllu, as a cultural avenue for the development of new corporate identities organized around jointly held land and communal decision-making. But Fabricant also examines how MST's efforts have been accompanied by expressions of hierarchy and violence, exacerbated by the influence of liberal individualism, including the emergency of liberalized markets promoting capital accumulation, private property, and economic mobility -all understood to promote selfinterest, competition and distrust.

Lazar's (2008) ethnography of grassroots mobilizations in El Alto convincingly shows how residents of this largely Aymara metropolis participate in multiple social networks, notably, as members of neighborhood associations and trade unions, and that these nested affiliations provide alteños the means to construct a "collective self" that can be quickly activated in times of crisis and conflict. Importantly, as Lazar explains, these are people who understand themselves to be indigenous, despite not being part of explicitly "indigenous" organizations. Lazar's goal is to show how, despite the push and pull of urban influences, incentives, and strains -at different points and in various ways she refers to self-interest, gossip, stratification, competition, market insertion and social fragmentationalteños nevertheless prioritize communal structures. As she notes, alteños are most likely to take part in actions that advance collective demands, and which exhibit the values of participation, obligation, reciprocity, and organizational life. And Lazar's argument was on spectacular display in the successive mass street protests of the early 2000s in El Alto around water and gas. 
With its careful attention to the discourses and practices of class mobility in the small city of Sacaba, Shakow's (2014) ethnography registers this tension differently. Shakow shows how Sacaba's residents, neither subaltern nor elite, are poorly described by the MAS government's explicitly "Indianist" agenda. She explores instead the variable and inconsistent positions her interlocutors adopt vis-à-vis questions of race and class, at times affirming and at times rejecting an indigenous heritage. For Shakow, this ambivalence illustrates a more fundamental collision of moral imperatives. On the one hand, "superiority" is often criticized by Sacabeños as equating with goals of upward mobility, personal benefit, and clientelism, but is also exhibited in expressions of selfishness, mutual suspicion and envy, and dismissals of uneducated people "from the countryside." On the other, "egalitarianism" is positively connected with sometimes competing assertions of equality, leftists-indigenist participatory decision-making, and the perceived fragility of community, associated with prior eras of political organizing and disappearing amid the encroaching city.

Throughout these and many other accounts, the specter of individualistic actions and attitudes often serves to indicate threats to collective projects, or a Hobbesian breakdown of community, often connecting such attitudes with urban living. These are variously identified with basic acts of self-interest, or with the seeking of personal benefit, envy, gossip, distrust, character assassination, leadership competitions, goals of social mobility, or the transactional and factional attributes of patronage and clientage. Often, too, such characteristics are elided with broader critiques of the negative consequences of regimes of private property, privatization, and self-regulation, or with the assumptions underwriting liberal or neoliberal model of citizenship, most notably, the sovereign individual as the moral and political locus of rights and obligations. Without dismissing the many harms of neoliberal policies for Bolivians, we can nevertheless note that, with some exceptions, references to individualisms of various sorts, or to the liberal subject, are generally relatively ethnographically thin when compared to ethnographically much thicker accounts of indigenous movements or collective politics. At worst they are little more than rhetorical ciphers for "neoliberalism." More often they are presented in self-evident ways as morally problematic disruptions of indigenous projects rather than as ethnographic problems in their own right and deserving of additional unpacking. 


\section{Critique of Citizenship as Cultural Critique}

Thirty years after Albó described his paradox, Lazar takes up this puzzle again. As do other ethnographers of indigeneity in Bolivia, she counterposes collective indigenous social organization and communal solidarity with neoliberal individualism. Nevertheless, she is clear that, in the context of the organization of effective social movement protest actions, despite the tensions introduced by competing incentives, ultimately, communal structures and collective values supersede individual desires and associated factionalism. But she takes this a step further, inviting us to understand alteños' struggles - their efforts to articulate a collective self and their factional rivalries - as an alternative model of relating to the state, or citizenship, that extends and complicates familiar liberal assumptions about individual responsibilities and rights. Lazar suggests that citizenship is better treated as a "bundle of practices," which in the alteños' case she calls "cholo citizenship" (2008, 1519). Lazar develops a sophisticated account of what the concept, cholo citizenship, encompasses, including the rural and urban mix of values and commitments expressed by many in-migrating alteños, such as the importance of residence or place-based and collective affiliations.

Lazar's exploration of indigenous social movement activism is at once a means to critique conventional liberal understandings of citizenship and a source for renovating the meaning and conditions for this concept in order to incorporate indigenous alteños' collective forms of political mobilization. In so doing, she addresses a frequent topic in contemporary ethnographies of Bolivia. The centrality of "citizenship" as a recurrent concern has several sources. Perhaps most obviously, the continuous social ferment that brought Evo Morales and the MAS to power called attention to lingering realities of second-class citizenship since the 1952 Revolution, while demanding rights, greater inclusion, and more direct influence upon governance and decisionmaking about national resources. In turn, the MAS years have been characterized by the state's efforts to revisit and to transform citizenship to accommodate specifically indigenous forms of political organization (see Albro 2010b).

Concurrent with these political developments in Bolivia has been renewed academic attention to processes of state formation, most notably, consequences of a late twentieth century shift from so-called corporatist to neoliberal models of governance, with indigenous assertions of selfdetermination understood to pose the most direct challenge to the neoliberal 
privileging of "the sovereign individual rather than group" (Canessa 2012, 204). The work of Deborah Yashar (2005), in particular, has regularly been cited by researchers exploring how such models, often unintentionally, promoted spaces of indigenous autonomy, while foregrounding the multiple and contested terms of citizenship. Against this background, Bolivia emerged as a major regional case for the ethnographic study of new and collective forms of the exercise of indigenous citizenship rights.

My examination of the so-called Water War described how protest leaders appropriated the state's own multicultural language of "customary law" (usos y costumbres) as the connective tissue providing cultural depth and durability helping to coordinate popular opposition to state actions, effectively using the precedent of ancestral patrimony and indigenous rights as sources of "deep citizenship" animating their collective mobilization (Albro 2005b). In a very different context, Bret Gustafson (2009) focused on tactics of "insurgent citizenship" in the course of his careful study of a Guarani movement for bilingual and intercultural education, begun in the mid-1990s. Gustafson attends to Guarani public discourse about education, but also about violence, as providing meaning and form to indigenous resurgence in Guarani country. Such discourse offers a way to claim and to transform public space through the "performance of alternative models of citizenship in practice" $(2009,16)$, which he understands in intercultural terms as encompassing at once state and Guarani sources of legitimacy, authority and power. In comparable fashion, Fabricant's account of "agrarian citizenship" for her MST counterparts incorporates their efforts to re-imagine small-scale agricultural production as collective and participatory, while using ayllu stories as a cultural and historical basis to connect alternative cosmologies and ideas of sacredness to the environment $(2012,128)$. But this is also a hybrid conception of citizenship, with MST members mixing "indigenous values and capitalistic logic," and the goals of individual smallholding success in the market with performances of collective land invasions and of shared environmental stewardship.

A corpus of ethnographies from the global north has considered the consequences and effects of neoliberal policies and dispositions in Bolivia. These ethnographic choices, however, have also promoted attention to forms of political indigeneity, as a collective politics and as a specifically indigenous rejection of neoliberalism and its attributes. Bolivia's Aymara president, Evo Morales, routinely decries the inhumanity of "savage capitalism" in his public interventions. Ethnographers have followed suite, negatively contrasting a Lockean liberal subject with its indigenous alternatives. 
One relatively thicker ethnographic engagement with the liberal (or neoliberal) has been as instantiated in law and policy, where such policymaking has had describable consequences for the terms of engagement between specific indigenous groups and the Bolivian state, as Postero (2007, 123-163) explores when considering the impacts of the 1994 Law of Popular Participation (LPP) for Guarani efforts to claim collective territory. Postero's discussion of "postmulticultural citizenship" in this case references Guarani struggles to demand radical changes in the relation between the state and civil society through intentional reformulations of citizenship rights, as a question of the political negotiation of participation, belonging, exclusion, and of the ordering of public space. Too often, however, reference to liberal or neoliberal subjecthood is as an assumed context for perceived individualistic conduct disruptive of collective indigenous projects, used as a foil or counterpoint to indigeneity -the primary crux of ethnographic attention and solidarity. "Neoliberal," "multicultural," "citizenship," "capitalism," "decolonization," "the state," and comparable vocabularies of politics and governance, meanwhile, function less as ethnographic invitations and more as intentions of cultural critique.

\section{Revisiting Cholo Heritage}

If not directly ethnographically equated with the liberal subject, the hierarchical and personalistic political practices of patronage and clientage, with their associated transactional implications of material benefit and individual political advancement, are frequently assumed to describe nonindigenous arenas of political contest in Bolivia. The term describing such practices - política criolla- appears to suggest their non-indigenous origins. But in Quillacollo, one finds a colorful multilingual vocabulary for clientage, which also routinely references Andean cultural conceptions of reciprocal exchanges, their manipulation, or perceived violation (Albro 2010a, 58-79). The kinds of transactional expectations so often associated with clientage are typically embedded within idiom of ritual godparenthood (or compadrazo), generally interpreted to be a colonial import to Bolivia. But as situations merit, these same transactions are also treated as expressions of "ayni" (a kind of exchange of equivalents informing indigenous Andean social relationships). Given evident social pressures to contribute resources to social events, it is not uncommon for people to argue over what does and doesn't count as ayni in such circumstances. A moral calculus derived from indigenous Andean sensibilities of social obligation matters greatly for the public accounting of 
such events and is very much a part of how clientelism is interpreted in Quillacollo.

"Egoismo," or selfishness, is an often-heard complaint, and usually a charge with the intent of identifying cholo-like qualities and clientelistic attitudes. But the same conduct is just as likely to elicit accusations of "Ilunk'u," a term reserved for the behavior of an ambitious, non-reciprocal and two-faced operator. In Quillacollo's political discourse, the figure of the Ilunk'u references Andean practices of reciprocal obligation as a cultural expectation, but with a mixture of intimacy and estrangement, where expectations of reciprocity are as often asserted in their violation. Importantly, Ilunk'us, as egoistas, exemplify a ubiquitous sort of political subjecthood with little apparent epistemological connection to the liberal subject, and draw on connections to an indigenous heritage, but in ways not necessarily embedded in a collective indigenous project. Llunk'us are, instead, notorious for their self-aggrandizing manipulations of Andean idioms of reciprocity, exchange and cooperation.

Quillacollo, the small satellite city, has an important story to tell about the changing significance of what it means to be indigenous in contemporary Bolivia. Indigeneity, as part of this urban landscape, has become a more capacious category than previously. In so becoming, it is less about the empowerment or cultural re-imagining of collective indigenous political projects and more a critical point of reference in public and often political debate. Quillacollo's políticos readily acknowledge their indigenous heritage, but this is at best a partial and contentious legacy. If "cholo" is historically pejorative, in Quillacollo's context of significant geographic and social mobility where many residents are from someplace else, the label also acknowledges forms of cultural practice associated with popular and indigenous sources of self-making. "Quillacollo, as a whole, is almost completely made up of cholos!" noted a local político and cultural activist. Debated claims of indigenous heritage among the city's so-called cholos and in an environment of unknowable or rumored ancestry and generational estrangement, however, often provide a shared basis of political collaboration.

Stephen Greenblatt used the term "self-fashioning" to identify an important dimension of the cultural construction of self, drawing attention to identity as a self-conscious process of the manipulation, dramatization, and commentary upon, cultural codes about community, tradition, and authority, over the course of peoples' careers. For Greenblatt $(1980,9)$, self-fashioning also involves some "loss of self," and he exposes the fiction of Renaissance era individual freedom while attending to constraints. Quillacollo offers its own 
version of self-fashioning, as an urban milieu in which indigenous questions matter a great deal, but most often as debated, provisional, and partial public claims. If people actively participate collectively in local base organizations, their identities and careers are not summed up by such participation. What I have called "cholo politics" operates within and through arrays of Andean cultural discourses and practices, as these contribute to the construction of cultural and political selves, and careers, and where a stance of intimacy with and alienation from indigenous ancestries provides productive room for maneuver people need to build shared political affinities.

\section{Works Cited}

ABERCROMBIE, Thomas. 1998. Pathways of Memory and Power: Ethnography and History among an Andean People. Madison, WI: University of Wisconsin Press.

ALBÓ, Xavier. 1977. La paradoja aymara: Solidaridad y faccionalismo. Cuadernos de Investigación No. 8. La Paz: CIPCA.

---. Thomas Greaves and Godofredo Sandoval. 1981. Chukiyawu: La cara Aymara de La Paz. Cuaderno de Investigación No. 20. La Paz: CIPCA.

ALBRO, Robert. 2005a. "The Indigenous in the Plural in Bolivian Oppositional Politics." Bulletin of Latin American Research 24(4): 433-453.

---. 2005b. "The Water is Ours, Carajo! Deep Citizenship in Bolivia's Water War." Social Movements: An Anthropological Reader. June Nash, ed. Malden, MA: Blackwell. 249-271.

---. 2010a. Roosters at Midnight: Indigenous Signs and Stigma in Local Bolivian Politics. Santa Fe, NM: SAR Press.

---. 2010b. "Confounding Cultural Citizenship and Constitutional Reform in Bolivia." Latin American Perspectives 37(3): 71-90.

---. 2018. "Bolivia's Indigenous Foreign Policy: Vivir Bien and Global Climate Change Ethics." Church, Cosmovision and the Environment: Religion and Social Conflict in Contemporary Latin America. Evan Berry and Robert Albro, eds. New York: Routledge. 99-122.

ARI, Waskar. 2014. Earth Politics: Religion, Decolonization, and Bolivia's Indigenous Intellectuals. Durham, NC: Duke University Press.

CANESSA, Andrew. 2007. "Who is Indigenous? Self-Identification, Indigeneity, and Claims to Justice in Contemporary Bolivia." Urban Anthropology and Studies of Cultural Systems and World Economic Development 26(3): 195-237.

---. $\quad$ 2012. "New Indigenous Citizenship in Bolivia: Challenging the Liberal Model of the State and its Subjects." Latin American and Caribbean Ethnic Studies 7(2): 201-221.

---. 2014. "Conflict, Claim and Contradiction in the New 'Indigenous' State of Bolivia." Critique of Anthropology 34(2): 153-173. 
FABRICANT, Nicole. 2012. Mobilizing Bolivia's Displaced: Indigenous Politics and the Struggle Over Land. Chapel Hill, NC: University of North Carolina Press.

GOLDSTEIN, Daniel. 2004. The Spectacular City: Violence and Performance in Urban Bolivia. Durham, NC: Duke University Press.

GOODALE, Mark. 2006. "Reclaiming Modernity: Indigenous Cosmopolitanism and the Coming of the Second Revolution in Bolivia." American Ethnologist 33(4): 634-649.

[https://anthrosource.onlinelibrary.wiley.com/doi/abs/10.1525/ae.200 6.33.4.634] downloaded Nov. 20, 2019.

GREENBLATT, Stephen. 1980. Renaissance Self-Fashioning: From More to Shakespeare. Chicago, IL: University of Chicago Press.

GRISAFFI, Thomas. 2010. "We Are Originarios... 'We Just Aren't from Here': Coca Leaf and Identity Politics in the Chapare, Bolivia." Bulletin of Latin American Research 29(4): 425-439.

HIMPELE, Jeffrey. 2008. Circuits of Culture: Media, Politics, and Indigenous Identity in the Andes. Minneapolis, MN: University of Minnesota Press.

LARSON, Brooke. 2019. "Revisiting Bolivian Studies: Reflections on Theory, Scholarship, and Activism since 1980." Latin American Research Review 54(2): 294-309.

LAZAR, Sian. 2008. El Alto, Rebel City: Self and Citizenship in Andean Bolivia. Durham, NC: Duke University Press.

MAMANI CONDORI, Carlos. 1991. Taraqu, 1866-1935: Masacre, Guerra, y "Renovación" en la biografía de Eduardo L. Nina Qhispi. La Paz: Ediciones Aruwiyiri.

POSTERO, Nancy. 2007. Now We Are Citizens: Indigenous Politics in Postmulticultural Bolivia. Stanford, CA: Stanford University Press.

RIVERA CUSICANQUI, Silvia. 1990. "Liberal Democracy and Ayllu Democracy in Bolivia: The Case of Norte de Potosí." Journal of Development Studies 26(4): 97-121.

SHAKOW, Miriam. 2014. Along the Bolivian Highway: Social Mobility and Political Culture in a New Middle Class. Philadelphia, PA: University of Pennsylvania Press.

YASHAR, Deborah J. 2005. Contesting Citizenship in Latin America: The Rise of Indigenous Movements and the Postliberal Challenge. Cambridge; New York: Cambridge University Press.

ZAMORANO VILLARREAL, Gabriela. 2017. Indigenous Media and Political Imaginaries in Contemporary Bolivia. Lincoln, NE: University of Nebraska Press.

\section{$(\mathrm{cc}) \mathrm{BY}$}



New articles in this journal are licensed under a Creative Commons Attribution 4.0 United States License.

This journal is published by the University Library System of the University of Pittsburgh as part of its D-Scribe Digital Publishing Program, and is cosponsored by the University of Pittsburgh Press. 